Institute of $\mathbf{F}_{\text {ood and }} \mathbf{A}$ gricultural $\mathbf{S}_{\text {ciences }}$

\title{
Alfalfa Production in Florida ${ }^{1}$
}

\author{
C. G. Chambliss ${ }^{2}$
}

Alfalfa is a high-quality legume forage crop that is mainly used for hay or silage but can be green chopped or grazed in some situations. It can be utilized by horses, dairy, and beef cattle. There is a great demand for alfalfa hay by the Florida horse and dairy industries. Thousands of tons of alfalfa hay are shipped into Florida each year. Thus, occasionally there is interest in growing alfalfa in the state.

Can alfalfa be grown in Florida? Yes (see Figure 1 ), but is it worth the effort? There is very little alfalfa grown in Florida, a fact which may be due to several reasons. Alfalfa is better adapted to the Midwest and other parts of the U.S. than it is to Florida's climate and soils. Alfalfa does best on heavier clay soils, while most Florida soils are very sandy. Alfalfa stands in Florida have a shorter productive life than stands in areas of the U. S. where the crop is better adapted. Stands will last up to three years on the heaver clay soil of the Panhandle region, about two years in north peninsular Florida, and one year on south Florida flatwoods. It takes more management skill to grow alfalfa than it does to grow bermudagrass or other tropical grasses. Alfalfa requires a higher soil $\mathrm{pH}$, a strict fertility regime and harvest schedule. Compared to bermudagrass, it is more difficult to get any legume hay crop dry enough to bale as hay. If the legume hay crop is rained on and then redried, the leaves tend to shatter. When developing a budget for growing alfalfa in Florida, add a little extra for the greater risk that exists when growing the crop in Florida as compared to growing it in the Midwest or West. Ask yourself: can alfalfa hay be bought and shipped in from other parts of the country cheaper than we can grow it ourselves? After saying the above, let us look at what it takes to grow alfalfa in Florida and ways to possibly make it a profitable enterprise.

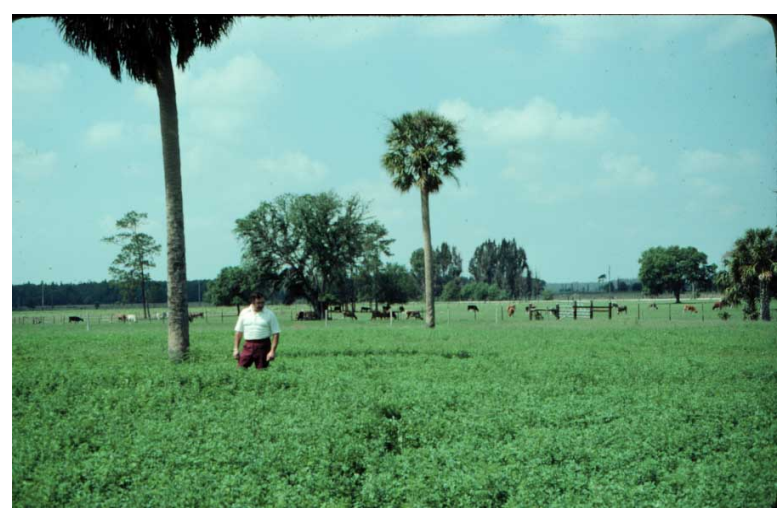

Figure 1. Alfalfa growing in Hillsborough County, Florida.

1. This document is SS-AGR-188, one of a series of the Agronomy Department, Florida Cooperative Extension Service, Institute of Food and Agricultural Sciences, University of Florida. Published February 2003. Visit the EDIS Web Site at http://edis.ifas.ufl.edu.

2. C. G. Chambliss, associate professor, Agronomy Department, Florida Cooperative Extension Service, Institute of Food and Agricultural Sciences, University of Florida, Gainesville, FL. 32611.

The use of trade names in this publication is solely for the purpose of providing specific information. UF/IFAS does not guarantee or warranty the products named, and references to them in this publication does not signify our approval to the exclusion of other products of suitable composition.

The Institute of Food and Agricultural Sciences is an equal opportunity/affirmative action employer authorized to provide research, educational information and other services only to individuals and institutions that function without regard to race, color, sex, age, handicap, or national origin. For information on obtaining other extension publications, contact your county Cooperative Extension Service office. Florida Cooperative Extension Service/Institute of Food and Agricultural Sciences/University of Florida/Christine Taylor Waddill, Dean. 


\section{Establishment}

\section{Site/Soil Selection}

Choose a site that has good drainage but is not a deep drought-prone sand. In other words choose "your best soil" on the farm. The soil should have a higher than average clay and organic matter content if possible. Alfalfa grows best on soils that have a high moisture-holding capacity, are fertile, deep and adequately drained. Alfalfa plants will develop a deep root system if root growth is not restricted by acid subsoil, hard pans (west Florida), or high water tables (south Florida flatwoods). Alfalfa does not like "wet feet" (Figures 2 and 3). A deep root system allows the alfalfa plants to be more drought-tolerant. Certain municipal spray fields that have developed a high $\mathrm{pH}$ but are well-drained and irrigated may be excellent sites for growing alfalfa.

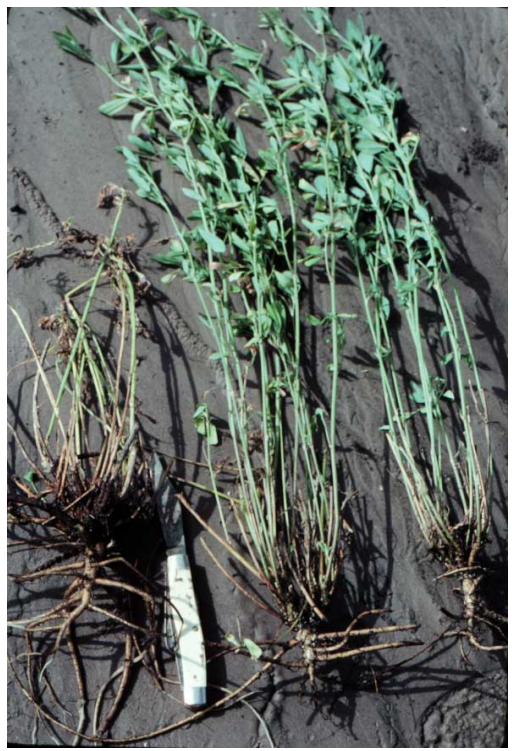

Figure 2. Restricted root growth due to high water table.

Once the alfalfa stand has deteriorated to the point that it is no longer economical to harvest, a new planting should be established on a new field. Do not replant into an old stand--rotate. If the new planting must go back on the same field, try to fallow the field for at least 3 months before replanting.

\section{Is Irrigation Needed?}

Alfalfa has a high water requirement. It has been grown in Florida without irrigation, but on the droughty upland sands irrigation will be needed to

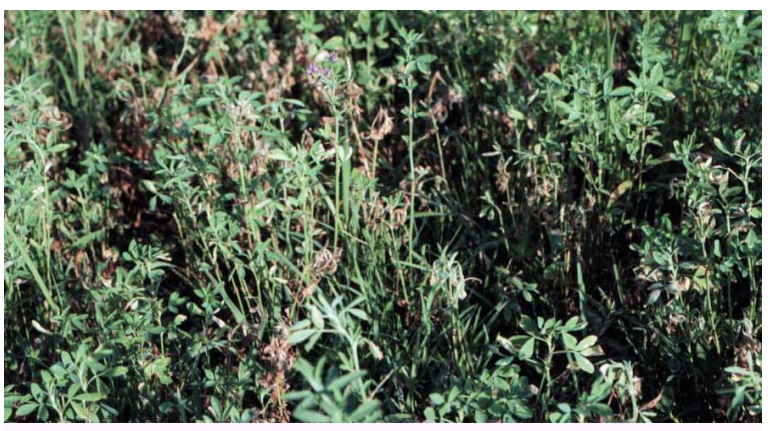

a.)

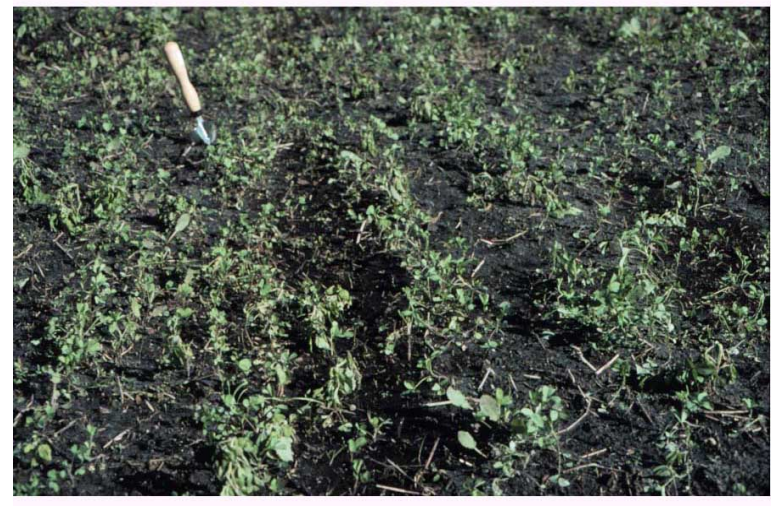

b.)

Figure 3. Alfalfa plants dying due to flooding.

ensure production in the spring, which is the prime growing season for alfalfa in Florida.

\section{Liming/pH and Fertilization}

Give careful attention to lime and fertilizer requirements of alfalfa. Soil samples should be taken in the spring or summer so that if lime is needed, it can be applied (and incorporated 6 inches deep) at least two to three months before planting in the fall. Sufficient lime should be applied to raise the $\mathrm{pH}$ to 6.0 to 6.5 .

If the magnesium $(\mathrm{Mg})$ is below 100 pounds per acre, one ton per acre of dolomitic lime should be applied as part of the liming program. Apply phosphorus and potassium according to soil test recommendations. This may require initial applications of 80 to 125 pounds per acre of $\mathrm{P}_{2} \mathrm{O}_{5}$ and 120 to 160 pounds per acre of $\mathrm{K}_{2} \mathrm{O}$ applied in split applications. Apply all of the $\mathrm{P}_{2} \mathrm{O}_{5}$ and $50 \%$ of the $\mathrm{K}_{2} \mathrm{O}$ fertilizer in late fall on established stands or just before seeding. Apply the remaining $\mathrm{K}_{2} \mathrm{O}$ in early spring. Removal of plant nutrients by grazing is not as great as when plants are mechanically harvested. If the alfalfa is mechanically harvested rather than 
grazed, apply an additional $30 \mathrm{lb} \mathrm{P}_{2} \mathrm{O}_{5} / \mathrm{A}$ and $60 \mathrm{lb}$ $\mathrm{K}_{2} \mathrm{O} / \mathrm{A}$ after each harvest. An additional application of $100 \mathrm{lb}$ of $\mathrm{K}_{2} \mathrm{O} / \mathrm{A}$ in June or July may increase summer survival of alfalfa. Apply 20 pounds of sulfur per acre in the spring as potassium or magnesium sulfate.

What about micronutrients? Apply $3 \mathrm{lb}$ of boron/A per year to alfalfa in three $1 \mathrm{lb} / \mathrm{A}$ applications. To grow alfalfa, most Florida soils need additional boron. A boron deficiency causes "alfalfa yellows," which takes the form of a general yellowing and dropping of leaves (Figure 4). Copper and zinc fertilizer may be needed if soil $\mathrm{pH}$ is above 6.5. There may be certain slow release micronutrient products available that would supply all of the micronutrients including boron.

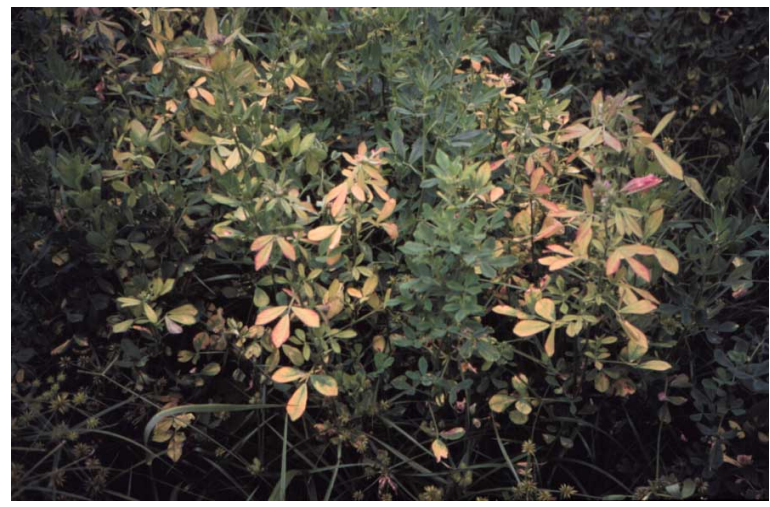

Figure 4. Boron deficiency: "alfalfa yellows".

\section{Variety Selection}

A non-dormant type with good disease and nematode resistance should be used in Florida. Varieties grown in the Midwest are not suitable.

The best variety to grow in Florida for hay production is "Florida 99". Another variety "AmeriGraze 702", may be suitable for use in Northwest Florida for both hay and grazing.

\section{When and How to Plant}

Plant alfalfa in the early fall so that the stand can become well established before the first frost. Plant between September 15 and November 1 in North Florida. Plant between October 15 and November 15 in South Florida.
By planting in early- to mid-October in North Florida seedlings should be strong enough to survive the first frost or freeze. Alfalfa may suffer some frost damage, but it will recover. Alfalfa should not be planted after the last suggested planting date. December and January plantings may be lost to hard freezes and the seedlings of later plantings (Feb.-March) will not be strong enough to withstand the high temperatures of May and June.

Seedbed: The seedbed should be well prepared so that it is free of trash, level, smooth, and compacted with a landroller or cultipacker. Plant material from the previous crop should be well decayed. This means that seedbed preparation should start two months prior to the expected planting date. If possible, plant into a seedbed that is moist but not excessively wet, and plant during a cool dry period. This will reduce the chance of seedling damping off.

Seed inoculation: The seed should be inoculated just before planting with nitrogen fixing bacteria that are specific for alfalfa. Use a commercial sticker to stick the inoculant to the seed. See EDIS publications SS-AGR-154, Inoculation of Agronomic Crop Legumes and SS-AGR-56, Nitrogen Fixaton and Inoculation of Forage Legumes.

Seeding rate and depth: Use a drill to plant 12 to 15 pounds per acre in rows 6 to 10 inches apart. The soil should be firmly packed around the seed. Plant to a depth of 0.6 to 0.8 inches. If a drill is not available, broadcast 18 to 22 pounds of seed per acre, harrow lightly, and cultipack. A higher seeding rate is needed because some seed will be placed too deep or too shallow. Alfalfa seed should germinate quickly with seedlings emerging in 5 to 6 days. Seedlings grow rapidly in comparison to many other plants.

\section{Weed Control}

Start with a clean-tilled seedbed. If the area to be planted has a large reserve of weed seed, it may be appropriate to use a "stale seed bed" treatment. This requires preparing the seedbed, letting weed seed germinate and then spraying them with Roundup before planting the alfalfa into the undisturbed seedbed using a drill. 
Several herbicides are registered for use in alfalfa production. Before planting, contact your farm chemical dealer for appropriate herbicides to use.

\section{Insects}

Insects may be a problem at any time of the year. Alfalfa fields should be checked weekly for insect damage so that appropriate measures can be taken before serious damage occurs (Figure 5). In the early spring, aphids may be present but are usually suppressed by the blood-red lady beetle. Insecticides may need to be used to control the alfalfa weevil, which occurs from late February to early June. In the fall (early Sept. to Nov.) alfalfa may be infested by the two-striped looper, fall armyworm, corn earworm, beet armyworm and the velvetbean caterpillar. All of these pests can be economically controlled with insecticides. If an insect infestation is found a few days before the normal harvest date, the alfalfa should be harvested early. If insects remain after harvesting and are present when new growth starts, spraying may need to be done at that time. See the insect control guide for the latest recommendations or EDIS publication ENY 402 Insect Management in Pastures.

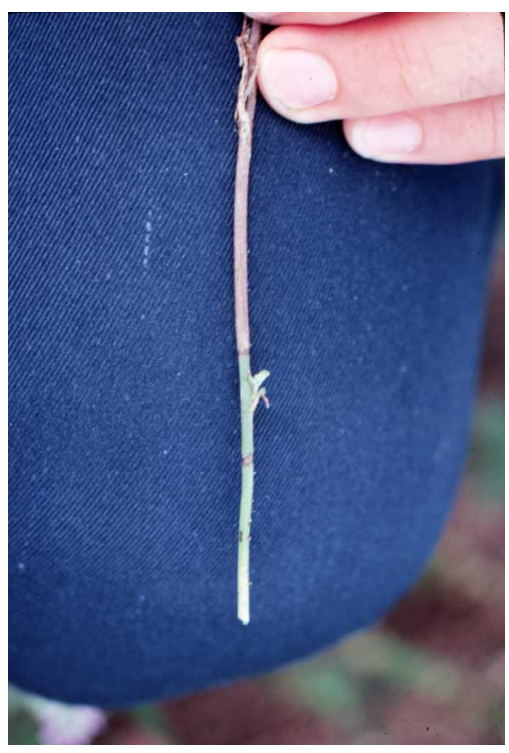

Figure 5. Alfalfa stem girdled by three-cornered alfalfa leaf hopper.

Several other insects such as the three-cornered alfalfa hopper and various species of blister beetle may occaisionally be a problem. The main concern with blister beetles is that they contain a toxin that will kill a horse if the beetle or parts of its body are consumed when feeding alfalfa hay.

\section{Diseases}

Although several fungal diseases may affect alfalfa, no control by use of fungicides is recommended.

Rust causes small brown spots surrounded by a yellow halo to form on leaves. With heavy infection, leaves turn yellow and prematurely drop off the plant. Infection builds as the plants mature. If harvest is delayed beyond the early bloom stage, considerable defoliation with loss of yield and quality can occur. Alfalfa must be harvested in a timely manner. Another leaf disease is Stemphyllium leaf spot, which causes light to dark brown spots with a concentric ring pattern. These spots are larger than those associated with rust. Other diseases including pathogenic fungi that attack the roots of alfalfa may occur. "Florida 99 " alfalfa has resistance or tolerance to a number of diseases as well as tolerance to certain pathogenic nematodes.

\section{When to Take the First Harvest}

The following factors need to be considered when planning a harvest: 1) maintaining a good stand, 2) yield, 3) quality, and of course 4) weather conditions. In order to extend the life of the stand, alfalfa must be allowed to reach the bloom stage before the first harvest is taken.

Alfalfa planted in the fall in Florida will not be ready for harvest until the early spring of the following year (approximately 4 months after planting). Subsequent harvests should also be taken at the early bloom stage. Don't wait for flowers to appear at the top of plants. First flowers develop below the top. On the other hand, harvesting before flowers appear reduces root reserves which will shorten stand life. Another indicator of when to harvest is the appearance of new shoots at the bottom (crown area) of the alfalfa plants. This is your next crop and you do not want to cut these young shoots when you harvest; therefore watch both flowering and new shoot development to determine when to harvest. The crop should be harvested if new shoots appear even though there may be little if any 
flowering. Cut the alfalfa at 2 to 4 inches above the soil surface. As plants mature and reach full flower, yield increases but quality decreases. Harvesting at early flower is a good compromise between maximum yield and maximum quality. In some situations yield may actually decrease at full flower because of severe leaf drop due to leaf diseases.

After the first harvest is taken in the spring, alfalfa will need to be harvested about every 28 to 30 days (early flower). But, what about the weather? If conditions are not suitable for making hay, harvest as chopped silage or roll bale silage (Figure 6). Don't wait for good hay-making weather. If you wait, you may have severe leaf drop due to buildup of leaf diseases and you are also using up time when the next crop should be growing. The next crop may be further delayed because you will likely cut off the new shoots at the bottom of the plants when you harvest late. Cutting off these young shoots also reduces the energy reserves and weakens the stand.

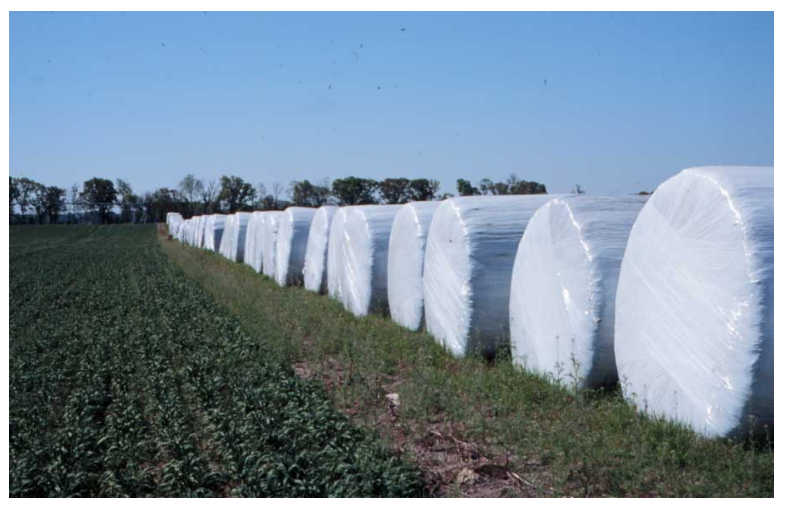

Figure 6. Roll bale silage.

How much yield can be expected? "Florida 99" should produce anywhere from 4 to 6.5 tons of hay per acre per year. Protein will average about $15 \%$ and TDN (total digestible nutrients), 55\% or higher.

\section{Hay Harvesting Tips}

Alfalfa may be baled in the large round bales, but the market for small, rectangular bales may be more profitable. If alfalfa can be baled at low enough moisture to prevent molding, use the small rectangular bale and sell to the horse market; otherwise the large round bale will be suitable for the dairy and beef market.
When harvesting, use a cutter with a roll-type conditioner. Do not use the abrasion type conditioner used on grasses. Spread the swath over as wide an area as possible to promote faster drying. Ted or rake the swath before the leaves have dried below 40 percent moisture. Below $40 \%$, leaves may be lost. If hay drys below $40 \%$ before raking into a windrow, wait and rake in the morning when the dew is still on to reduce leaf loss. As the plants dry in the windrow, check moisture content. Bale when plants are at $15 \%$ moisture or lower. If bailed at a higher moisture, consider using a propionic acid type hay preservative to inhibit molding. A 3- to 4-day dry period may be needed to make hay. If the hay is rained on just before baling - go get the wrapping machine and be prepared to bale as roll bale silage (if the crop is not ready to bale as hay) within one day of being rained on! Further attempts to dry and bail the crop may result in significant leaf loss; if the crop does not dry quickly, mold and other rotting organisms will begin to work on the plant material. Anyone growing alfalfa in Florida should be prepared to take some harvests as silage. If silage is not an alternative, then consider green chop or rotationally grazing the stand during the summer rainy season (July-August).

\section{Silage Harvesting Tips}

Cut and allow the crop to wilt to 60 to $65 \%$ moisture (two to three hours on a hot, clear day). Bale and store as roll-bale silage or chop and store as bagged silage. If storing as bagged silage, a pickup head will be needed on the field chopper. Use a silage innoculant to enhance the ensiling process.

\section{Grazing}

If alfalfa is grazed, rotational grazing (stocking) should be used. This allows a rest period for the plants to recover. The producer may want to use strip grazing. An electric fence is used to allow a large number animals on a small area of the alfalfa field. This allows the animals to graze off the alfalfa in the strip in a very short period of time (one to two days) after which they are given a new strip to graze and are fenced out of the grazed area until it recovers. Animals can bloat when grazing alfalfa and should be monitored daily. Bloat prevention products are available. 
Alfalfa could be used as a creep grazing crop for calves. Fall born calves can start grazing significant amounts of forage by the time they are four months old. Calves born before or at the time alfalfa is planted will be old enough to graze about the time the alfalfa is ready to be grazed.

One acre should be enough for 6 or more calves. Calves would be expected to gain an extra 0.3 to 0.5 pounds per day.

\section{Summary and Precautions}

Alfalfa can be grown in Florida but should not be grown by a producer who is not willing or able to plant, fertilize, and manage it properly. Alfalfa requires fertile soil with above average water holding capacity, which is well drained both on the surface and internally. Soils which may become waterlogged or flooded for extended periods must be avoided (Figure 3). Horner and Ruelke (1980) advise that "Individuals who have not had previous experience with alfalfa should plant only a small acreage the first year to determine how well it grows on their particular farms."

\section{References}

Horner, E. S., and O. Charles Ruelke. 1980.

Florida 77 Alfalfa and Recommended Management Practices for Its Prodcution. Circular S-271 Agricultural Experiment Stations, Institute of Food and Agricultural Sciences, University of Florida, Gainesville, FL. 